\title{
20411 ピストンの遮熱溶射技術の開発
}

Development of Heat Resistant Thermal Spray Technique for the Piston

\section{○ 関根 優志（山梨大） \\ 中澤 一貴（山梨大） \\ 正 園家 啓嗣（山梨大） \\ 正 中村 正信（山梨大）}

Masashi SEKINE, University of Yamanashi, Takeda-4, Kofu, Yamanashi

Kazuki NAKAZAWA, University of Yamanashi, Takeda-4, Kofu, Yamanashi

Keiji SONOYA, University of Yamanashi, Takeda-4, Kofu, Yamanashi

Masanobu NAKAMURA, University of Yamanashi, Takeda-4, Kofu, Yamanashi

\begin{abstract}
Resently there are many problems about energy. Especially the energy problem depending on limited resources is serious. The $70 \%$ or more of all energies consumed in the world are limited resources. Research utilizing the unlimited resources including natural energy are carried out so not to deplete its limited resources. The level of some researches is in the practical stage, and the teknology require a lot of time to spread in the world. Thus, improving the energy conversion efficiency of the internal combustion that is widely spread in the world is important. So we aimed to make the heat resistant coating on the piston by a thermal spray technique to improve the energy conversion efficiency of the internal combustion at simple and low cost. In this study, we carried out tensile type pin-test for evaluating the adhesive force and thermal cycle test for evaluating the thermal fatigue property.
\end{abstract}

Key Words: Thermal Spray, Piston, Heat Resistant

\section{1. 粕言}

近年, 環境破壊や原発の危険性の再認識などエネルギー に関する問題が多く挙げられており，特に有限資源に依存 したエネルギ一問題が顯著になっている，現代社会では $70 \%$ 以のエネルギーが有限資源を消費することによっ て得られている. その有限資源を枯渴させないため自然エ ネルギーなどの無限資源を利用する研究が数多く行われ おり，実用段階のものもあるが，低コスト化，高寿命化な どの問題が多々あり，それらが社会に普及するには多大な 時間が必要となる. そんな中，現在の社会で広く普及して いる内燃機関のエネルギー変換効率を向上させることは， 重要なことである.

ところで表面改質技術の一つとして溶射がある.溶射は 基材の上に溶融した金属粒子を吹きつけ，皮膜を形成する 技術であり，低コストで部材表面性能をの性質を向上させ ることが可能である.

そこで溶射技術によってピストンに遮熱皮膜を形成し， 簡易かつ低コストで内燃機関のエネルギー変換効率を向 上させることを目的とし，本研究では遮熱溶射皮膜の熱疲 労特性及び密着力の評価を行った.

熱痏労特性の評価方法は高温状態と常温状態を綝り返 す熱サイクル試験を採用した

密着力の評価方法は引張り型ピンテストを採用した. 一 般的な溶射皮膜の界面強度評価方法はJISH8402 で規格化 されているが，この手法ではいくつかの欠点が存在する. まず第一に皮膜と治具の接合に接着剂を使用しているた め，接着剂が溶射皮膜に浸透してしまう. 第二に近年，プ ラズマ溶射や高速フレーム溶射などの密者力の強い溶射 法が開発されため, 皮膜の密著力が接着郕の接着力を上回 ってしまい，正確な密着力の測定が行えない。

これらの課題を解決するため提案された界面強度評価 方法の一つが引張り型ピンテスト(1)である.

本研究では，アルミナ，部分安定化ジルコニア，SUS316 を溶射材料とした溶射皮膜について，熱サイクル試験によ る熱疲労特性とピンテストによる密着強度を評価した。

\section{2. 実験方法}

\section{1 供試材}

基材は実際にピストンに使用されている $\mathrm{Al}-13 \% \mathrm{Si}$ を用 いた．また，ピンテストにおいては比較材として SS400 も用いた. 溶射皮膜の密着力は基材の硬さの影響を受ける ので(2), Al-13\%Siに近い硬さをもつ SS400を基材とした.

遮熱皮膜となる溶射材はアルミナ $\left(\mathrm{Al}_{2} \mathrm{O}_{3}\right)$, 部分安定化 ジルコニア $\left(\mathrm{ZrO}_{2}+8 \% \mathrm{YO}_{2}\right)$, および SUS316 とし，上記材 料を溶射した試験片は膜厚, 気孔率を比較パラメーターと した.

Table1に試験に用いる各溶射試験片を示す.

Tablel Properties of sprayed coatings

\begin{tabular}{|c|c|c|c|c|c|}
\hline \multicolumn{2}{|c|}{ Top coating } & \multicolumn{2}{|c|}{ Bond coating } & \multirow{2}{*}{ Porosity [\%] } & \multirow{2}{*}{$\begin{array}{c}\text { Base } \\
\text { material }\end{array}$} \\
\hline Materials & Thickness [ $\mu \mathrm{m}]$ & Materials & Thickness [um] & & \\
\hline \multirow{3}{*}{$\mathrm{Al}_{2} \mathrm{O}_{3}$} & \multirow{3}{*}{$\begin{array}{c}300 \sim 320 \text { and } \\
100 \sim 120\end{array}$} & \multirow{3}{*}{$80 \% \mathrm{Ni}-20 \% \mathrm{Cr}$} & \multirow{3}{*}{$80 \sim 100$} & 20 & $\mathrm{Al}-13 \% \mathrm{Si}$ \\
\hline & & & & 5 & \\
\hline & & & & 5 & SS400 \\
\hline \multirow{3}{*}{$\mathrm{ZrO}_{2}+8 \% \mathrm{YO}_{2}$} & \multirow{3}{*}{$\begin{array}{c}300 \sim 320 \text { and } \\
100 \sim 120\end{array}$} & \multirow{3}{*}{ CoNiCr AlY } & \multirow{3}{*}{$80 \sim 100$} & 20 & $\mathrm{Al}-13 \% \mathrm{Si}$ \\
\hline & & & & 5 & \\
\hline & & & & 5 & SS 400 \\
\hline \multirow{3}{*}{ SUS316 } & \multirow{3}{*}{$\begin{array}{c}300 \sim 320 \text { and } \\
100 \sim 120\end{array}$} & & & 20 & $\mathrm{Al}-13 \% \mathrm{Si}$ \\
\hline & & & & 5 & \\
\hline & & & & 5 & $S \$ 400$ \\
\hline
\end{tabular}

\section{2 熱サイクル試験}

実際のディーゼルエンジンのピストンは, シリンダー内 で燃料を燃焼する際に $400^{\circ} \mathrm{C}$ 程の熱が加わる. 本実験では

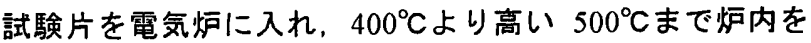
加熱，その状態を保持せずエアーを吹き付けて常温まで冷 却する熱サイクル試験を行った.たたし試験の1サイクル は約 30 分である. 
2.3 ピンテスト (3)

Fig.1 に溶射中のピンの固定方法および引張試験方法を 示す. 溶射は事前にピンとディスクをロックナットで固定 して行った。 引張試験時はロックナットを外し，引張試験 用の冶具を装着した. 冶具の固定は両端にユニバーサルロ ックジョイントを用い, 油圧式万能型引張試験機のクロス

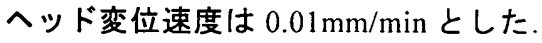

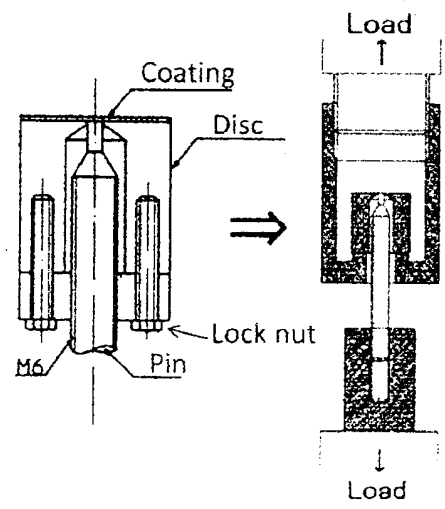

Fig. 1 Overviev of specimen and tensile test method

\section{3. 試験結果}

\section{1 熱サイクル試験結果}

常温から $500^{\circ} \mathrm{Cの}$ 熱サイクルを 100 回繰り返した試験片 の断面をマイクロスコープで観察した結果のうち膜厚 300 $\mu \mathrm{m}$ の試験片を Fig.2〜4に示す. アルミナ，SUS316 皮膜 では問題なかったが, 部分安定化ジルコニア皮膜では一部 にはく離が確認された

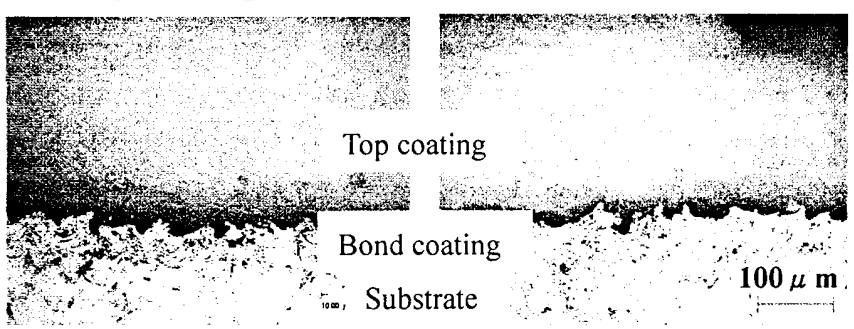

Porosity of top coating : $20 \%$ Porosity of top coating :5\%

Fig. 2 Microstructure of test pieces (Top coating : $\mathrm{Al}_{2} \mathrm{O}_{3}$ )

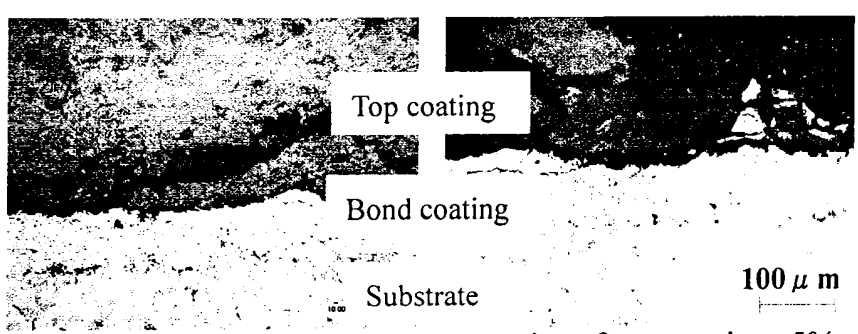

Porosity of top coating :20\% Porosity of top coating :5\%

Fig.3 Microstructure of test pieces (Top coating : $\mathrm{ZrO}_{2}+8 \% \mathrm{YO}_{2}$ )

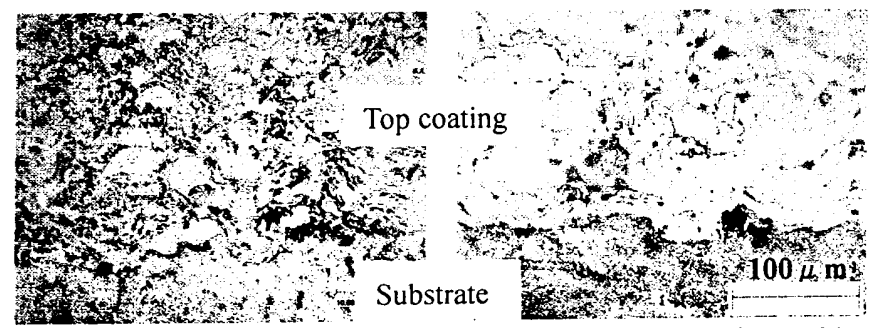

Porosity of top coating : 20\% Porosity of top coating :5\%

Fig.4 Microstructure of test pieces (Top coating : SUS316)
3.2 ピンテスト結果

Fig.5 に膜厚 $300 \mu \mathrm{m}$ の溶射試験片のピンテスト結果を 示す. 部分安定化ジルコニア及び SUS316の破断荷重は 8 〜 10kgfであり，アルミナの破断荷重は $4 \mathrm{kgf}$ 程度であった.

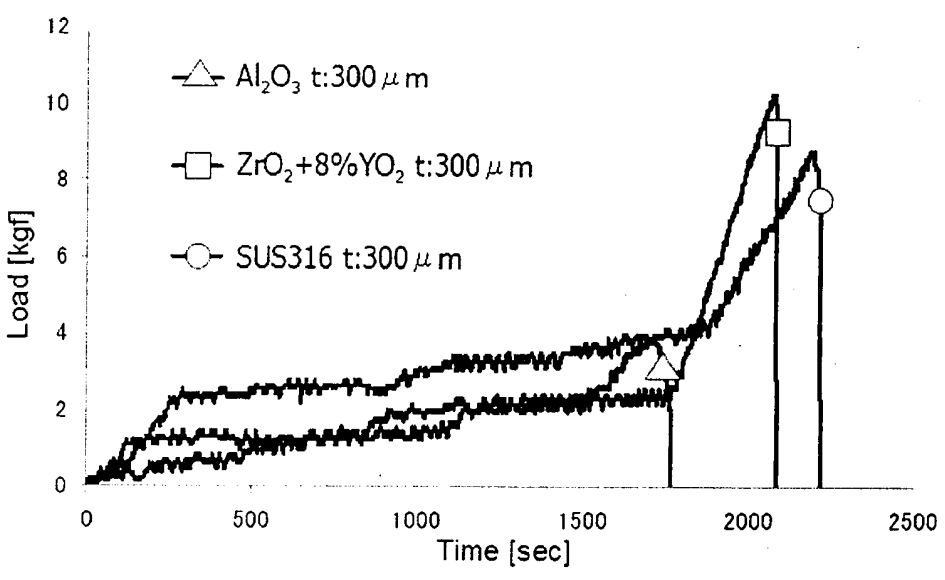

Fig.5 Experimental results of pin-test

\section{3 総合評価}

熱サイクル試験，ピンテストの両試験結果と材料物性， コストを含めた総合評価を Table2に示す。

Table2 Experimental results and properties of sprayed coatings

\begin{tabular}{|c|c|c|c|c|c|c|c|c|c|c|c|}
\hline Top coating material & \multicolumn{4}{|c|}{$\mathrm{Al}_{2} \mathrm{O}_{3}$} & \multicolumn{4}{|c|}{$\mathrm{ZrO}_{2}+8 \% \mathrm{YO}_{2}$} & \multicolumn{3}{|c|}{ SUS316 } \\
\hline Thickness $[\mu \mathrm{m}]$ & \multicolumn{2}{|c|}{300} & \multicolumn{2}{|c|}{100} & \multicolumn{2}{|c|}{300} & \multicolumn{2}{|c|}{100} & \multicolumn{2}{|c|}{300} & 100 \\
\hline Porosity [\%] & 20 & 5 & 20 & 5 & 20 & 5 & 20 & 5 & 20 & 5 & $20 \quad 5$ \\
\hline Over view & 0 & 0 & 0 & 0 & 0 & 0 & 0 & 0 & 0 & 0 & 0 \\
\hline Microstructure & 0 & 0 & 0 & 0 & $x$ & $x$ & $\triangle$ & $\triangle$ & 0 & 0 & 0 \\
\hline Adhesiv & - & 0 & - & $\triangle$ & - & $\triangle$ & - & 0 & - & 0 & - \\
\hline Heat conductivity & 0 & 0 & 0 & 0 & (a) & (a) & (C) & (a) & 0 & 0 & $\mathrm{O}$ \\
\hline linear expansivity & $\triangle$ & $\triangle$ & $\triangle$ & $\triangle$ & $\triangle$ & $\triangle$ & $\triangle$ & $\triangle$ & 0 & 0 & 0 \\
\hline Cost & 0 & 0 & 0 & 0 & $\triangle$ & $\triangle$ & $\triangle$ & $\triangle$ & 0 & 0 & 00 \\
\hline
\end{tabular}

\section{4. 結言}

アルミナ，部分安定化ジルコニア，SUS316 溶射皮膜の 熱疲労特性, 密着力, 基材との線膨張係数の近さ、コスト の観点から評価すると，SUS316 がピストンへの遮熱皮膜 として優れていることがわかった

今後はピンテストに大きく影響するパラメーターを考 慮した実験を行っていく予定である.

参考文献

（1）井上好章，小野豊明，納富啓，出羽昭夫，豊田政男， 塚本光夫，引張り型ピンテストによるプラズマ溶射皮 膜の界面強度評価法, 溶接学会論文集、第 9 巻, 第 1 号, (1991),

$167-173$

（2）木下貴章，丸山徹，小林武，溶射皮膜の密者性に及ほ す基材表面硬さの影響, 第 93 回全国講演大会講演論文 集，(2011)，43-44

（3）園家啓嗣，中村正信，引張り型ピンテストによる耐磨 耗溶射皮膜の密着強度評価法の検討，溶射，第 48 巻, 第 3 号, (2011)，92-97 